\title{
Quality Examination of Fisheries as an Implementation of Fisheries Products
}

\author{
Vindy Sulistyo Vardhani ${ }^{1 *}$, Amiek Soemarmi ${ }^{2}$, Sekar Anggun Gading Pinilih ${ }^{3}$ \\ \{vindysulistyovardhani@gmail.com ${ }^{* 1}$, amiek_soemarmi@live.undip.ac.id ${ }^{2}$ \\ sekar_anggun@live.undip.ac.id $\left.{ }^{3}\right\}$
}

Fakultas Hukum, Universitas Diponegoro, Jl. Prof. H. Soedarto, S.H., Semarang, Indonesia $50275^{1,2,3}$

\begin{abstract}
This study aims to analyze and describe the efforts from the Department of Fisheries in conducting quality inspection of fishery products in Pacitan Regency in order to find the obstacles in maintaining fishery product quality a and overcome them. The research method used is qualitative method with a normative juridical approach. Meanwhile, the research is presented in a descriptive-analytical form. The results showed that the efforts were a control of fishery products which included an inspection of the quality of fishery products that met the eligibility requirements of fish processing, quality assurance systems, and safety of fishery products. The Constraints faced include: origin of the product that is not accompanied by complete data, lack of awareness of maintaining the quality of fishery products, traditional fish processing and marketing business actors, and lack of adequate UPP PMP2KP personnel. Some efforts to overcome these obstacles are to increase the role and tasks of the Fisheries Service, quantity and quality of personnel, facilities, and infrastructure. From the findings, the Pacitan Regency Government is expected to make a Regent Regulation related to the implementation of fishery product quality assurance and carry out socialization to the private sector and the community.
\end{abstract}

Keywords: Quality Assurance; Implementation; Fisheries Products

\section{Introduction}

The conception of an archipelagic state of Indonesia shows that the territorial waters of Indonesia are wider than the land area. [1] The Indonesian Ocean is geographically located in the Equatorial region and has a tropical climate to have a consequences for the wealth of species and fisheries resources. [2]

Fisheries resources is one of the fields that has a bright future because of its high potential with abundant fish resources. However, its management and utilization are not optimal so that all fishery activities in Indonesia are regulated by Law Number 45 of 2009 concerning Amendments to Law Number 31 of 2004 concerning Fisheries, [3] the aim is to regulate and protect fishery activities from pre-production until the results are ready and safe for consumption by the community.

Pacitan Regency is one area with high potential and capture fisheries production. According to Pacitan beach fisheries data in 2014, fish were dominated by tuna species, namely baby tuna at $1,007,949 \mathrm{~kg}$ and big aye tuna at $4,530 \mathrm{~kg}$. This shows that it is quite promising for fisheries production business. This potential can be developed to support economic growth and improve the welfare of people who make a living in the field of 
fisheries. [4] The amount of capture fisheries production in Pacitan Regency one of which also raises problems, among others, related to the quality and safety of fishery products.

The processing of fish and fishery products must meet the requirements of the feasibility of fish processing, quality assurance systems, and safety of fishery products that is regulated by; 1) Government Regulation Number 57 of 2015 concerning Quality Assurance and Safety Products for Fisheries Products, and; 2) Law Number 45 of 2009 concerning Amendment to Law Number 31 of 2004 concerning Fisheries. For this reason, a quality check is conducted for all fishery products, both fresh fish and processed fish in order to obtain quality fisheries that are safe for human health. In the field of fisheries to ensure the quality and safety of fishery products, in fact Indonesia has required fisheries supply chains to implement a quality system through the Integrated Quality Management Program (PMMT) based on the HACCP concept. [5] Based on the background that has been described, the author was inspired to compile a scientific work (journal) with the title, "Quality Examination of Fisheries as an Implementation of Fisheries Results in Pacitan District."

Issues that will be discussed in this paper are related to the efforts made by the Fisheries Service in conducting quality inspection of fishery products in Pacitan Regency and the obstacles faced by the Fisheries Service in maintaining fishery product quality standards in Pacitan Regency and how to overcome them.

\section{Research Method}

This study uses a qualitative method with a normative juridical approach. This research is presented in a descriptive-analytical form, namely describing and analyzing all findings in the form of documents and interviews, which are then arranged in the form of scientific papers (journals) to describe the problem with the title: Quality Inspection of Fishery Products as Implementation of Fisheries Product Supervision in Pacitan Regency.

\section{Discussion}

\subsection{Efforts Made by the Fisheries Service in Examining the Quality of Fisheries Products in Pacitan Regency}

The Government's involvement in fisheries management according to Nikijuluw, consists of three functions, namely: [6]

1. The allocation function, which is carried out through regulations to divide resources in accordance with the stated objectives;

2. The distribution function, which is carried out by the government in order to realize fairness and fairness in accordance with the sacrifices and costs borne by everyone, in addition to the government's partiality to those who are excluded or weaker;

3. The stabilization function, which is intended so that the activities of utilizing fish resources do not have the potential to cause instability that can damage and destroy the social and economic order of the community.

Fisheries management is governed by Law No. 45 of 2009, amended from Law Number 31 of 2004 concerning Fisheries, while the process must be based on the principles of benefits, 
justice, togetherness, partnerships, independence, equity, integration, openness, efficiency, sustainability, and sustainable development.

The fisheries resources are quite numerous, both in terms of quality and diversity of forms to be utilized for the welfare of the community. Management of fish resources must be done well based on fairness and equity. [7]

Fisheries resource management is an integrated process starting from information gathering, analysis, planning, consultation, decision making, resource allocation and implementation, in order to ensure the continuity of productivity and the achievement of management objectives. [8]

The main objectives of fish resource management according to Widodo and Nurhakim are for the following: [9]

1. Maintaining the sustainability of production, especially through various regulations and enhancements;

2. Improving the economic and social welfare of fishermen; and

3. Meeting the needs of industries that utilize the production.

The policy plan that has been established and then implemented in the midst of the community has a purpose in the welfare of people's lives (expectation). Expectation is to formulate what is desired from the implementation of tasks, good fisheries can support all aspects of community life and the economy of the community can be improved, not only for the benefit of the current generation, but also for future generations. As for the measurements and standards of expectation, which is to provide socialization and coaching. [10]

The efforts made by the Fisheries Service in conducting quality inspection of fishery products in Pacitan Regency are as follows:

\subsubsection{Implementation of Duties and Functions of the Pacitan Regency Fisheries Service}

The Fisheries Service is an element of implementing Regional Autonomy. The Department of Fisheries has the task of carrying out the affairs of the Regional Government in the field of Fisheries and Maritime Affairs based on the principle of autonomy and the task of assistance as well as other tasks in accordance with the policies that have been determined based on applicable laws and regulations, [11] one of them is related to inspection of fishery quality results.

Pacitan Regency Fisheries Service in accordance with Article 3 of Pacitan District Regulation Number 71 of 2016 has the task of helping to carry out marine and fisheries affairs which include aquaculture, capture fisheries, fisheries product management and coadministration tasks given by the Regency. [12]

The role of the Pacitan Regency Fisheries Service as referred to in article 34 of Government Regulation Number 57 of 2015 concerning Fishery Product Quality and Safety Assurance System and Increasing the Value Added of Fishery Product Products states: [13]

Paragraph (1): The Minister, relevant ministers, governors, and regents/mayors in accordance with their authority provide guidance to business actors and the Fisheries community in implementing the Fishery Product Quality and Safety Guarantee System and increasing the Added Value of Fishery Product Products;

Paragraph (2): Guidance as referred to in paragraph (1) is carried out through outreach, counseling, coaching and enhancing community participation. 
Implementation of the quality assurance and safety system for fisheries products can be carried out by the Fisheries Department of Pacitan Regency to provide guidance and monitor the fisheries businesses in Pacitan. With the cooperation and synergy between all stakeholders in implementing a quality assurance and food safety system both in terms of guidance, control and supervision, it is expected to minimize the use of hazardous chemicals such as formalin in fisheries products on the market.

\subsubsection{Fishery Product Quality Assurance in Pacitan Regency}

The fishing industry has become one of the most processed commodities in Indonesia with an extraordinary amount of fish abundant from Indonesia's marine resources, a challenge for the government to help communities around the coast to increase productivity in terms of marine product management, [14] especially related to quality assurance and safety of fishery products.

The application of the quality assurance and safety system for fisheries products is a single step and eventually becomes an integrated series, starting before the production or stages of raw materials that are in accordance with the standards and their hygiene until the output is a product certification that is safe for human consumption. The whole series involves the role of various stakeholders, both the central government (BKIPM KKP RI and the Directorate General of PSDKP) and the regional government in charge of marine and fisheries.

The role of the Pacitan Regency Fisheries Office in accordance with its authority is to provide guidance to business players and the fisheries community, in implementing a quality assurance and fishery product safety system, as well as increasing the added value of fishery products.

The implementation of a quality assurance and safety system for our fisheries products in Pacitan Regency requires consistency and commitment in the application of fishery product quality (LPPMHP) as well as existing quality development personnel. Cooperation and synergy between all stakeholders in implementing a quality assurance and food safety system in terms of guidance, control and supervision can minimize the use of hazardous chemicals such as formalin in fisheries products on the market.

Every person and processing unit in Pacitan Regency is required to check the fishery products before being consumed and/or traded to the community, both domestically and abroad (exported). The inspection was carried out by the Technical Implementation Unit (UPT) of the Quality Testing and Development of Maritime and Fisheries Products (PMP2KP) Surabaya, which was formed based on the East Java Governor Regulation No. 115 of 2016 concerning the Organization and Work Procedures of the Technical Implementation Unit of the Maritime Affairs and Fisheries Office of East Java Province. UPT Quality Testing and Development of Marine and Fisheries Products (UPT PMP2KP) has the task of carrying out some of the tasks of the Office in the technical areas of testing, quality assurance and development of marine and fishery products.

This UPP PMP2KP under the Office of Maritime Affairs and Fisheries (DKP) is an institution or institution that issues quality test certification and the development of processed food products from seafood and fisheries. UPT Quality Testing and Development of Marine and Fisheries Products (PMP2KP) Surabaya is a Product Certification Institute (LS Pro) for Fisheries Products in the East Java Provincial Maritime and Fisheries Service Office which has been accredited by the National Accreditation Committee (KAN) with LSPr-056-IDN date May 24, 2017. 
Quality inspection of the results of this inspection is carried out by sampling or sampling from the fishery products to be tested for quality. Sampling and sampling size for fishery products that will be used for consumption and/or foreign trade must be done at random. Testing or technical activities consisting of the determination, determination of one or more properties or characteristics of a product, material, equipment, organism, physical phenomenon, process or service, in accordance with established procedures.

Decree of the Head of the Fish Quarantine Agency, Quality Control and Safety of Fishery Products of the Ministry of Maritime Affairs and Fisheries Number KEP. 04/BKIPM/2011 concerning Delegation of Authority to the Inspection and Certification Body in the Issuance of Health Certificates, [15] Article 1 explains that a laboratory is a room or place used to carry out monitoring and/or testing of the quality of raw materials, semi-products and final products and substances hazards during the production process, whereas according to ISO/IEC Guide 2 1986 laboratories are agencies/institutions that carry out calibration and/or testing.

Every laboratory designated as a reference laboratory and/or testing laboratory must meet the requirements and be accredited as a testing laboratory by an internationally recognized accreditation body. Appendix II Decree of the Head of the Fish Quarantine Agency, Quality Control and Safety of Fishery Products Ministry of Maritime Affairs and Fisheries Number PER. 03/BKIPM/2011 concerning Technical Guidelines for the Implementation of Quality Assurance and Fisheries Product Safety Systems, explains that the requirements referred to are accredited based on ISO 17025 for test parameters that will be used as a reference and apply a quality management system as a laboratory for organizing comparative tests and/or proficiency tests. The quality of fishery products is the standard set of raw materials, supplementary materials, supporting materials, packaging compositions and others regarding the testing of each type of fishery product.

Based on the ability of the tests carried out by the laboratory, the laboratory can be grouped into three types, namely organoleptic laboratories that test physical properties (complete weight, central temperature, canned packaging, filth) and organoleptic or sensory samples, microbiology laboratories that test or identify microorganisms pathogens, their characteristics and characteristics, and chemical laboratories that test or analyze the content of chemicals in samples such as heavy metals, antibiotics, histamine, TVB-N, proximate, and others.

\subsubsection{Implementation of Fishery Product Quality Assurance in Pacitan Regency}

Implementation of quality control in general fish management based on good manufacturing practices (GMP), is carried out by; receipt of raw materials, sort I, washing with ice water, freezing, sort II, glassing, weighing, packaging and labeling as well as storage. [16]

Fishery products contain at least some quality aspects, namely; bio-techno-economic aspects (agriculture/fisheries), sanitation and hygiene aspects (health), commercial, industrial aspects, and legal aspects (legal). [17]

Indonesian aquaculture products face various challenges to improve competitiveness, both in product quality and efficiency in production. The biggest challenge for food products, including aquaculture products in Pacitan, the most important is food safety by prioritizing quality, both for export products and public consumption. Improving the quality of fishery products is more directed at providing food safety guarantees starting from raw materials to the end products that are free from contaminants according to market requirements. The Ministry of Maritime Affairs and Fisheries has formed a Competent Authority that has the authority to control the implementation of the Fishery Product Quality and Safety Guarantee 
System with the Directorate General of Fisheries Product Processing and Marketing (P2HP), the Directorate General of Aquaculture and the Directorate General of Capture Fisheries as the agency responsible for controlling the implementation of the Quality Assurance System and Yield Security in the community.

Quality Assurance and Safety of Fisheries Products emphasizes prevention efforts that must be considered and carried out from pre-production to distribution to obtain quality fishery products that are safe for human health. Improving the quality of aquaculture products is more directed at providing food safety guarantees from raw materials to the end products of aquaculture that are free from contaminants according to market requirements. Activities of the Quality Assurance and Safety Product for Fisheries carried out by the Directorate General of Aquaculture include:

1. Certifying Good Fish Cultivation (CBIB) for fish cultivation business;

2. Certifying Good Fish Hatchery (CPIB) for fish hatchery business;

3. Registering Feed for fish feed both domestic and imported production;

4. Registering Fish Medicines for fish medicines both in domestic and imported production;

5. Monitoring residues at the level of fish farmers on the use of fish medicines, chemicals, biological materials and contaminants.

The Government of Pacitan Regency through the Fisheries Service in the implementation of a quality assurance and safety system for fishery products by controlling fishery products which includes quality inspection of fishery products that meet the eligibility requirements of fish processing, quality assurance systems, and safety of fishery products.

Head of Fisheries Product Management Division of Pacitan Regency Fisheries Office stated that the implementation of fishery product quality assurance is intended as an effort to optimize the utilization of fishery resources in handling fishery products to produce products that can be marketed both domestically and for export destinations, which in turn will maintain stability and increase production and marketing of fisheries products. [18] In addition, Dhian Kurnia Widyamayanti added that food security must be guaranteed along the production chain, and all parties involved in the supply of fishery products are responsible for aspects of food safety. [19]

Handling of fishery products according to Pacitan Regency, namely processing fish and fishery products must meet the requirements of the feasibility of fish processing, integrated quality assurance systems, and safety of fishery products. Pacitan Regency Government in an effort to maximize fishery yields and provide higher economic value, it is necessary to process fishery products to obtain quality products so as to facilitate marketing of fishery products.

In addition, in order to improve quality and maintain fishery products that are consumed and/or traded to the public, both domestic and foreign, still meet hygiene requirements, it is necessary to provide guidance and guidance to fisheries processing and marketing activities, namely the Regional Government must carry out guidance and guidance for micro and small scale fishery product processing and marketing activities in implementing a quality assurance and fishery product safety system, achievement of certificate of processing feasibility, and certificate of implementation of integrated quality management.

\subsubsection{Supervision of the quality of fishery products}

Quality in fishery products is defined as the size of a product that is determined using the human senses (organoleptic) as a gauge of the good/bad of a product and food safety guarantees (food safety). Human senses that are commonly used to determine the quality 
measurement of a product are sight, smell, taste, touch and listener. The sight used can be used for parameters of uniformity, color, shape and dimensions of the product. [20]

Supervision is essentially intended to prevent mistakes and show the right way and remind purposes. Therefore, through the application of the principle of coordination, the nature of supervision can be optimal and is expected to be a solution in creating a balance, [21] namely the management of fishery products based on the principles of benefit, justice, togetherness, partnership, independence, equity, integration, openness, efficiency, sustainability, and sustainable development.

The Fisheries Service Office of Pacitan Regency together with the Fish Quarantine Center, Quality Control and Safety of Fisheries Products in Surabaya carry out quality control activities of domestic fishery products in traditional markets and TPI in Pacitan Regency. The purpose of this activity is to guarantee the quality and safety of domestic fishery products in the centers of healthy food providers, including in traditional markets, modern markets, fishing landing ports and fishery product collectors.

Dhian Kurnia Widyamayanti as the Head of Quality Development Section of the Pacitan Regency Fisheries Service stated that the target of controlling the quality of domestic fishery products for the Pacitan location is a traditional market and a fish landing port by forming an integrated team together with the Central for Fish Quarantine, Quality Control and Safety of Surabaya Fishery Products. [19]

The Pacitan Regency Fisheries Service together with an integrated team from the district department and related agencies conduct domestic quality control through sampling and laboratory testing and report the results to the center periodically. In addition to conducting quality control, the Fisheries Service Office of Pacitan Regency assesses the sanitation and hygiene of infrastructure at the point of supervision. As is known, the Ministry of Maritime Affairs and Fisheries as mandated in Presidential Instruction No. 1 of 2017 concerning the Healthy Living Community Movement is obliged to improve and expand the implementation of the movement to promote fish eating in the community and to oversee the quality and safety of fishery products.

Strategic steps taken to achieve these objectives include optimizing the availability of healthy and safe consumption of fish as healthy food, strengthening the quality assurance system and safety of fishery products, quality control in the market and healthy fish production centers and the provision of healthy fish-based culinary centers.

\subsection{Constraints faced by the Fisheries Service in Maintaining Fisheries Product Quality Standards in Pacitan Regency and Efforts to Overcome It}

General problems related to the implementation of supervision carried out by the government, namely:

1. The limited budget available to carry out supervision;

2. The unavailability of experts;

3. The lack of coordination between agencies;

4. The lack of community participation to carry out supervision; [22]

5. The unavailability of regulations regarding technical implementation.

Problems found in the implementation of activities in order to achieve targeted performance in the implementation of quality inspection of fishery products in Pacitan Regency, including: 
1. The unavailable data to support the origin of the product

2. The lack of awareness of fishermen on the importance of maintaining the quality of fishery products.

3. The traditional processing way when in terms of managing businesses, both individuals, cooperatives and the private sector resulting in creating poor product quality, technical requirements, sanitation, and hygiene.

4. The lack of UPT Quality Testing and Marine and Fisheries Product Development (PMP2KP) which spreads throughout the territorial waters in East Java with adequate personnel.

The solutions offered are related to the resolution of the problem, of course, grounded in its constraints. [23] The efforts made in overcoming the obstacles faced by the Fisheries Department in maintaining fishery product quality standards in Pacitan Regency, namely:

1. Increasing the role and duties of the Fisheries Service to be more careful in identifying problems that occur in the field. In handling fish, after the process of catching or harvesting, it plays an important role to obtain maximum fish selling value. One factor that determines the sale value of fish and other fishery products is the level of freshness.

2. Increasing the quality and quantity of personnel, facilities and infrastructure of the UPT Quality Testing and Marine and Fisheries Product Development (PMP2KP). One day improvement of fishery product quality certification is related to in process inspection.

3. Improving the Management of UPT Quality Testing and Development of Marine and Fisheries Products (PMP2KP) providing services to service users, always prioritizing quality and ensuring that testing is carried out professionally.

Implementation of efforts to overcome obstacles faced by the Fisheries Department of Pacitan Regency, is expected to be able to achieve the objectives of fisheries resource management for the welfare of the fishermen, supply of food, industrial raw materials, foreign exchange earners and find out the optimum portion of utilization by the fishing fleet and determine the number of catches allowed is based on the maximum sustainable catch. [24]

\section{Closing}

\subsection{Conclusion}

1. The Fisheries Service's efforts in conducting quality inspection of fishery products in Pacitan Regency aim to obtain quality and safe fishery products from pre-production to distribution center. The process is carried out by controlling and inspecting fisheries products quality to meet the requirements of fish processing feasibility, quality assurance system, and fishery product safety.

2. The constraints faced by the Fisheries Service in maintaining fishery product quality standards in Pacitan Regency include; the origin of products that are not accompanied by complete data, lack of awareness of the fishermen on the importance of maintaining the quality of fishery products, traditional processing and marketing businesses of fishery products, lack of UPT Quality and Marine Product and Fisheries Product Development (PMP2KP). Meanwhile, the efforts to overcome those include: 
improving the role and tasks of the Fisheries Service, increasing the quantity and quality of personnel, improving the facilities and infrastructure, and improving the management of the UPT Quality Testing and Development of Marine and Fisheries Products (PMP2KP).

\subsection{Suggestion}

1. For the Pacitan Regency Government: To make Regents Regulations related to the implementation of the Perda in regulating matters that do not cover yet by the previous Perda related to quality assurance of fishery products in Pacitan Regency;

2. For the Pacitan Regency Fisheries Office: To improve the coordination level with related parties in the preparation of programs and activities in the field of fisheries and maritime affairs. In addition, to further improve the implementation of quality inspection of fishery products;

3. For the fish processing industry in Pacitan Regency: To improve a good marketing strategy so that they can compete with other competitors. In addition, they need to always diversify products. 


\section{References}

[1] A. Diamantina, "Penegakan Hukum Pidana di Bidang Perikanan," Universitas Diponegoro, 2000.

[2] D. M. R. Siombo, Hukum Perikanan Nasional dan Internasional. Jakarta: Gramedia Pustaka Utama, 2013.

[3] Law Number 45 of 2009 concerning Amendment to Law Number 31 of 2004 concerning Fisheries. .

[4] and H. Deswanti, R. H., "Keragaman Penerapan Teknologi dan Kelayakan Usaha Pengolahan Ikan Tuna di Kabupaten Pacitan," Bul. Ilm. Mar. Sos. Ekon. Kelaut. dan Perikan., vol. 2, no. 1, pp. 29-35, 2016.

[5] D. H. Ndahawali, "Unit Pengolahan Ikan Wajib Memiliki Sertifikat Kelayakan Pengolahan," Bul. Matric, vol. 13, no. 1, 2016.

[6] V. P. Nikijuluw, Rezim Pengelolaan Sumber daya Perikanan. Jakarta: Pustaka Cidesindo, 2002.

[7] A. Putra, O. P. K., Soemarmi, A., \& Diamantina, "Pelaksanaan Tugas dan Wewenang Dinas Kelautan dan Perikanan dalam Pengolahan Hasil Perikanan di Kabupaten Pati," Diponegoro Law J., vol. 6, no. 1, pp. 1-15, 2017.

[8] Food and Agricultural Organization, Fisheries Management. Roma: FAO-Technical Guidelines for Responsible Fisheries, 1997.

[9] S. Widodo, J., and Nurhakim, Konsep Pengelolaan Sumberdaya Perikanan. Paper Training Fisheries Resources Management. Jakarta, 2002.

[10] R. Ishak, and Wahyu, "Pengawasan terhadap Usaha Bidang Perikanan oleh Pemerintah Daerah Kabupaten Kampar Tahun 2011-2012,” J. Online Mhs. Fak. Ilmu Sos. dan Ilmu Polit. Univ. Riau, vol. 1, no. 1, 2014.

[11] S. Koesoema, Y. A. H. A., Tisnanta, and Prayoga, "Pengawasan dinas perikanan dan kelautan terhadap pengendalian sumberdaya perikanan di kota Bandar Lampung," $J$. Hima Han, vol. 1, no. 2, pp. 1-9, 2014.

[12] Pacitan Regent Regulation Number 71 of 2016 concerning the Job Description Function and Work Procedure of the Fisheries Service in Pacitan Regency. .

[13] Government Regulation Number 57 of 2015 concerning Quality Assurance System and Safety of Fishery Products and Increasing Added Value of Fishery Products. .

[14] Z. Nahruddin, "Pemberdayaan masyarakat dalam pengelolaan hasil perikanan di Kelurahan Sumpang Binangae Kabupaten Barru," Otoritas J. Ilmu Pemerintah., vol. 4, no. 1, pp. 92-100, 2014.

[15] Decree of the Head of the Fish Quarantine Agency, Quality Control and Safety of Fishery Products of the Ministry of Maritime Affairs and Fisheries Number KEP. 04/BKIPM/2011 concerning Delegation of Authority to Inspection and Certificate Institutions in I. .

[16] N. W. P. Devi, K. P. T., Suamba, I. K., and Artini, “Analisis Pengendalian Mutu pada Pengolahan Ikan Pelagis Beku di PT Perikanan Nusantara (Persero) Cabang Benoa 
Bali,” J. Agribus. Agritourism, 2016.

[17] M. M. P. Husni, A., and Putra, Pengendalian Mutu Hasil Perikanan. Yogyakarta: Gadjah Mada University Press, 2018.

[18] Interview with Suprapto, Head of Fisheries Product Management Division, Pacitan Regency Fisheries Office, 18 March 2019. .

[19] Interview with Dhian Kurnia Widyamayanti, Head of the Quality Section of the Baina Office of Fisheries in Pacitan Regency, March 18, 2019.

[20] B. Waluyo, E., and Kusuma, Keamanan Pangan Produk Perikanan. Malang: Universitas Brawijaya Press, 2017.

[21] F. U. Puluhulawa, "Pengawasan sebagai Instrumen Penegakan hukum pada pengelolaan Usaha pertambangan Mineral dan Batubara," J. Din. Huk., vol. 11, no. 2, pp. 306-315, 2011.

[22] M. Natalis, A., Gutami, B., and Azhar, "Penegakan Sanksi Administratif Terhadap Pelaku Illegal Mining di Kabupaten Sekadau Provinsi Kalimantan Barat," Diponegoro Law J., vol. 6, no. 2, pp. 1-17, 2017.

[23] S. D. Rismawati, "Partisipasi perempuan dalam pusaran pem-bangunan daerah (Telaah Kritis atas Kendala dan Solusi)," Muwazah, vol. 4, no. 1, 2012.

[24] K. A. Boer, M., and Aziz, "Gejala tangkap lebih perikanan pelagis kecil di Perairan Selat Sunda," J. Ilmu-Ilmu Perair. dan Perikan. Indones., vol. 14, no. 2, pp. 167-172, 2007. 